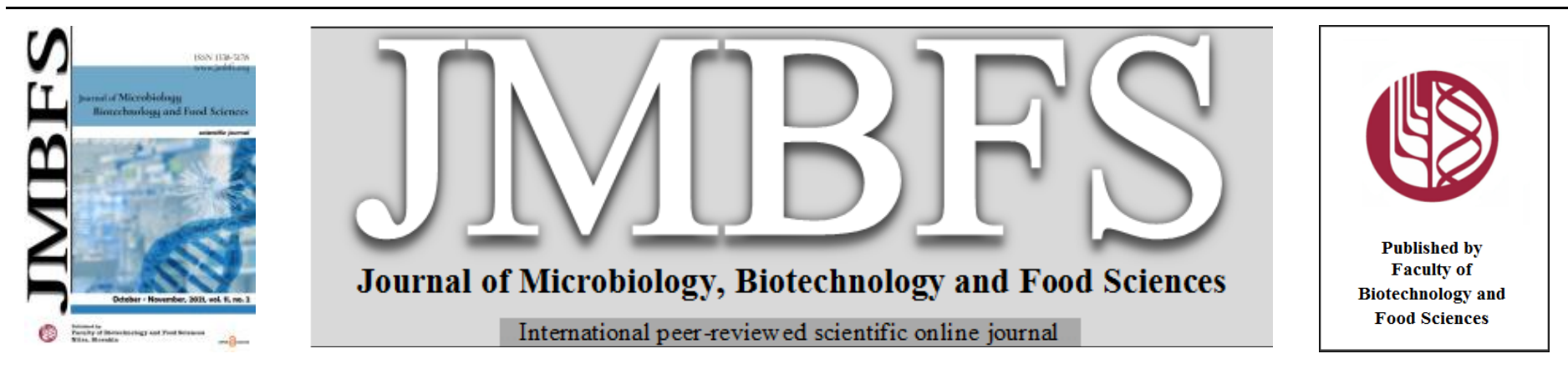

\title{
IMPACT OF THE GLOBAL REGULATOR SARA ON TOXINS PRODUCTION IN STAPHYLOCOCCUS AUREUS
}

\author{
Eman El-Baz ${ }^{1,2}$, Abdelaziz Elgaml ${ }^{1,3 *}$, Rasha Barwa ${ }^{1}$ \\ Address(es): \\ ${ }^{1}$ Department of Microbiology and Immunology, Faculty of Pharmacy, Mansoura University, Mansoura 35516, Egypt. \\ ${ }^{2}$ Students University Hospital, Ain Shams University, Cairo 11566, Egypt. \\ ${ }^{3}$ Department of Microbiology and Immunology, Faculty of Pharmacy, Horus University, New Damietta, 34518, Egypt.
}

*Corresponding author: elgamel3a@mans.edu.eg

https://doi.org/10.15414/jmbfs.4155

\section{ARTICLE INFO}

Received 2. 1. 2021

Revised 24. 4. 2021

Accepted 7. 5. 2021

Published 1. 10. 2021

Regular article

open $\partial_{\text {ACCESS }}$

\begin{abstract}
Staphylococcus aureus (S. aureus) is a Gram-positive bacterium that is responsible for many infectious diseases in human, some of which may be fatal. The regulation of toxins production and virulence factors in this pathogen is controlled by many global regulators including the staphylococcal accessory regulator, SarA. In this study, we outlined the influence of SarA on toxins production in $S$. aureus. The expression of genes encoding toxins was measured using real-time PCR and toxins production was quantitatively assayed. Gene expression and quantitative toxins production were compared in three staphylococcal strains; UAMS-1 wild type clinical strain, its $s a r A$ mutant strain and a revertant strain. Genes encoding for proteases (including $s s p A$, aur, $s c p A$ and $s s p B$ ), genes encoding for hyaluronidases (including hysA 1 and hysA2) and gene encoding for staphylokinase (sak) were upregulated in response to the sarA mutation. On contrary, genes encoding for lipases (including lip1 and lip2) were downregulated. Moreover, the quantitative production of protease, hyaluronidase and staphylokinase was significantly increased due to the sarA mutation. On the other hand, the quantitative production of lipase was significantly altered. Overall, our findings indicate that SarA is an effective global regulator of toxins production that can suggest new prospective therapeutics for the treatment of S. aureus infections.
\end{abstract}

Keywords: Gene expression; Global regulator; SarA; Staphylococcus aureus; Toxins production

\section{INTRODUCTION}

In the clinical context, Staphylococcus aureus (S. aureus) is considered the most pathogenic organism in the Gram-positive Staphylococcus genus (Bitrus et al., 2018). It is a commensal bacterium, which colonizes the majority of the human population (Tong et al., 2015). S. aureus becomes opportunistic when it gains access to open wounds, or when it colonizes populations suffering from lowered immunity including immunocompromised patients, diabetics, elderly people and children (Tong et al., 2015; Bitrus et al., 2018). This opportunistic pathogen can lead to high morbidity and mortality. S. aureus can cause a vast variety of diseases ranging from mild and moderate skin infections to more severe and lifethreatening infections such as endocarditis, food poisoning, osteomyelitis and toxic shock syndrome (Becker, 2018; Hamzah et al., 2019).

Disease severity and the multiple pathogenic implications of $S$. aureus are attributed to the diversity of virulence factors that act in a complicated harmonious manner such as the production of biofilm, surface proteins, exfoliative toxins, exoenzymes and exotoxins (Connolly et al., 2017). Staphylococcal ability to produce these virulence factors enables its attachment to the host tissues and evading the host immune system to subsequently cause its cellular and systemic toxic effect (Ionescu et al., 2015). Indeed, S. aureus produces many potent exotoxins, co-factors and exoenzymes, among which, proteases, lipases, staphylokinase and hyaluronidases are especially important (Lacey et al., 2016). The regulation of virulence determinant production in $S$. aureus involves several global regulatory loci; of these, SarA, a regulatory nucleic acid binding protein, is particularly important (Arvidson \& Tegmark, 2001; Jones et al., 2008; Mauro et al., 2016; Jenul \& Horswill, 2019).

$S$. aureus secretes many types of proteases that play a crucial role in the staphylococcal proteolytic effects, breaking down host peptide bonds. Protease production is mediated by different operons encoding seven serine proteases $(\operatorname{ssp} A)$ and serine protease-like proteins $(s p l s)$, two cysteine proteases (staphopain A, $s c p A$ and staphopain B, $s s p B$ ) and a metalloprotease (aureolysin, aur) (Singh \& Phukan, 2019). These proteases are able to lyse many host proteins such as fibrinogen and fibronectin (Pietrocola et al., 2017). Besides protease production, $S$. aureus is known as a potential lipase producer. Lipase production by this pathogen enables immune evasion by interfering with the phagocytosis by human granulocytes (Chen \& Alonzo, 2019). Lipases can inactivate antimicrobial lipids, and also facilitate host cell lysis by helping degradation of cell membrane lipids. Lipase effect on host lipids results in release of free fatty acids from lipid stores (Cadieux et al., 2014; Chen \& Alonzo, 2019). There are two types of lipases; Sal1 and glycerol ester hydrolase (Geh = Sal2) encoded by gehA and gehB, respectively (Nguyen et al., 2018; Chen $\&$ Alonzo, 2019). Furthermore, staphylokinase is a 136 amino acid long co-factor found associated with the cell surface and in the environment of cell culture. It can bind to host antibacterial peptides including $\alpha$ defensins and revoke their antibacterial action. It does not have proteolytic ability on its own, but its activity arises after the formation of 1:1 complex with plasmin to form Sak-plasmin active complex that converts plasminogen (PLG) into plasmin with broad proteolytic range (Pietrocola et al., 2017; Tam \& Torres, 2019). Besides, the ability of S. aureus to go through tissues rich in hyaluronic acid (HA) is based on its secreted hyaluronidase enzyme or hyaluronate lyase that was previously known as the spreading factor. Hyaluronidase is encoded by hysAl, however, in some $S$. aureus strains, another type of hyaluronidase enzyme was found that is about $75.9 \%$ identical to hyaluronate lyase 1 and is encoded by hysA2 (Tam \& Torres, 2019).

In the current study we depicted effect of the global regulator SarA on protease, lipase, staphylokinase and hyaluronidase production in $S$. aureus. This was fulfilled by comparing the gene expression as well as quantitative production of these toxins between wild type, sarA mutant and revertant $S$. aureus strains.

\section{MATERIALS AND METHODS}

Bacterial strains and culture conditions

S. aureus strains utilized in this study are described in Table 1 (Beenken et al., 2003; Morrison et al., 2012). Tryptic soy broth (TSB) was used for routine cultivation of $S$. aureus strains. Moreover, extraction of toxins and their quantitative assay were carried out in TSB. 
Table 1 Bacterial strains used in this study

Bacterial strain

Characters

Reference

Clinical standard isolate;

UAMS-1 virulent; methicillin sensitive;

(Beenken et al. 2003; Morrison $e t$ al., 2012)

\section{UAMS-1 sarA} mutant

UAMS-1, sarA mutant

\section{(Beenken et al.,}

2003; Morrison et al., 2012)

\section{UAMS-1 sarA}

revertant

\section{(Beenken et al., 2003; Morrison et al., 2012)}

\section{Measurement of bacterial growth}

S. aureus strains were inoculated in TSB and incubated at $37^{\circ} \mathrm{C}$ overnight on a shaker incubator adjusted at a speed of $150 \mathrm{rpm}$. Thereafter, an aliquot from each previously grown cultures was subcultured into fresh TSB and subsequently incubated with shaking at $37^{\circ} \mathrm{C}$. The bacterial cell density and growth rate were monitored by determining the optical density of the cultures at $600 \mathrm{~nm}\left(\mathrm{OD}_{600}\right)$ every 60 minutes to establish the growth curve and to determine the bacteria growth phases.

\section{Real-time PCR (rt-PCR)}

S. aureus strains were inoculated in TSB and incubated at $37^{\circ} \mathrm{C}$ with shaking, and RNA isolation was established during the log phase of bacterial growth. Cell pellets were harvested by centrifugation at $10000 \mathrm{rpm}$ for 5 minutes at $4^{\circ} \mathrm{C}$. Then, the resultant cell pellets were mixed with $300 \mu \mathrm{L}$ of triazole reagent (TRI reagent $^{\circledR}$, Sigma-Aldrich, USA) and $150 \mathrm{mg}$ glass beads $(212-300 \mu \mathrm{m}, 50-70$ U.S. sieve, unwashed, Sigma-Aldrich, USA). The reaction mixtures were heated in a heating block adjusted at $60^{\circ} \mathrm{C}$ for 20 minutes with vortexing every 5 minutes, and then were vortexed for 30 minutes. Afterwards, the cells were incubated in a $-80^{\circ} \mathrm{C}$ freezer for 3 minutes, then incubated at $37^{\circ} \mathrm{C}$ for another 3 minutes. This cycle of freezing and thawing was repeated 3 times to disrupt the cell integrity and was followed by centrifugation at $6000 \mathrm{rpm}$ for 5 minutes at $4^{\circ} \mathrm{C}$. Following the TRI reagent ${ }^{\circledR}$ manufacturer's protocol, RNA was precipitated, air dried for 10 minutes and resuspended in $20 \mu \mathrm{L}$ of RNase free water. RNA samples were treated with DNase set (Qiagen, Hilden, Germany), according to the manufacturer's protocol, and then were kept at $-80^{\circ} \mathrm{C}$. The quality of isolated RNA was checked and its concentration was measured using NanoDrop (Thermo Fisher Scientific inc., Massachusetts, USA). Using SensiFAST ${ }^{\text {TM }}$ cDNA synthesis kit (Bioline, Bloomberg, USA), synthesis of cDNA was performed according to the manufacturer's guidelines from the purified RNA. Real-time PCR (rt-PCR) was conducted using 5x HOT FIREPol ${ }^{\circledR}$ EvaGreen HRM Mix (Solis BioDyne, Tartu, Estonia) according to the manufacturer's guidelines and the Rotor-Gene Q (Qiagen, Hilden, Germany). Each reaction mixture consisted of $4 \mu \mathrm{L}$ of $5 \mathrm{x}$ HOT FIREPol ${ }^{\circledR}$ EvaGreen HRM Mix, $2 \mu \mathrm{L}$ of template cDNA, 12 $\mu \mathrm{L}$ of sterile water (PCR grade), $1 \mu \mathrm{L}$ of forward primer $(250 \mathrm{nM})$ and $1 \mu \mathrm{L}$ of reverse primer $(250 \mathrm{nM})$ (Table 2$)$. In every PCR run, negative control reaction mixtures were included and were prepared by excluding the reverse transcriptase enzyme or cDNA template from the reaction mixture. In each run, a pool $(8 \mu \mathrm{L})$ was created from the cDNA of tested strains, and 4 dilution points from this pool were included in each run to establish a standard curve. PCR was carried out according to the conditions; primary activation for 15 minutes at $95^{\circ} \mathrm{C}$. Then, 45 cycles of denaturation for 12 seconds at $95^{\circ} \mathrm{C}$, annealing for 20 seconds at the appropriate temperature and extension for 20 seconds at $72^{\circ} \mathrm{C}$. Amplification specificity was determined from the amplicon melting curves. $16 S$ rRNA was used as a house-keeping gene to normalize the expression of tested genes. The RNA concentration of each sample was calculated through comparing $C_{t}$ of each gene sample to the established standard curve. In these experiments, the housekeeping gene was used as an endogenous reference gene, where the level of expression of each gene in different samples was calculated compared to the house-keeping gene by the comparative method $\left(\Delta \Delta \mathrm{C}_{\mathrm{t}}\right)$ using UAMS-1 as a calibrator sample (Schmittgen \& Livak, 2008).

\begin{tabular}{|c|c|c|c|c|c|}
\hline Gene & Accession number & & Nucleotide sequence 5' 3' & Position & Size (bp) \\
\hline \multirow[t]{2}{*}{$16 S \mathrm{rRNA}$} & JTJK01000002 & $\mathrm{F}$ & AACTAAGCTTAAGGGTTGCG & $417--601$ & 185 \\
\hline & & $\mathrm{R}$ & GGAGCATGTGGTTTAATTCG & & \\
\hline \multirow[t]{2}{*}{$\operatorname{ssp} B$} & JTJK01000001 & $\mathrm{F}$ & CATTAGCAACAACTGCTAGG & $141--382$ & 242 \\
\hline & & $\mathrm{R}$ & GCGTACATTATACCCTGAAG & & \\
\hline \multirow[t]{2}{*}{$\operatorname{sspA}$} & JTJK01000001 & $\mathrm{F}$ & TGAGTTACCACCAGTTGTAC & $364--601$ & 238 \\
\hline & & $\mathrm{R}$ & CGAAGGTGATTTAGCAATCG & & \\
\hline \multirow{2}{*}{ hysA1 } & JTJK01000001 & $\mathrm{F}$ & СTAATGGATGATATGCTCAC & $601--843$ & 243 \\
\hline & & $\mathrm{R}$ & GGCAGAATCTTGAACATAAG & & \\
\hline \multirow[t]{2}{*}{ hysA2 } & JTJK01000002 & $\mathrm{F}$ & ACATTGATCATCAAGACGTC & $881--1100$ & 220 \\
\hline & & $\mathrm{R}$ & TCATTTTCACGACTGATAGC & & \\
\hline \multirow[t]{2}{*}{ lip2 } & JTJK01000001 & $\mathrm{F}$ & CATGATAAAGCAGCACCAAC & $541--786$ & 246 \\
\hline & & $\mathrm{R}$ & TTTATCTGTCGGTTTCTCCG & & \\
\hline \multirow[t]{2}{*}{ lip1 } & JTJK01000002 & $\mathrm{F}$ & GTCTGCTTTTTGTCTATCGC & $322--572$ & 251 \\
\hline & & $\mathrm{R}$ & ATTCAAGAGTAGACTTCGGG & & \\
\hline \multirow[t]{2}{*}{$\operatorname{scpA}$} & JTJK01000002 & $\mathrm{F}$ & AAGTTAATGTCGAGGACAAG & $119--363$ & 245 \\
\hline & & $\mathrm{R}$ & ATCCTTAGTGACTTTTGGTG & & \\
\hline \multirow[t]{2}{*}{$s a k$} & JTJK01000002 & $\mathrm{F}$ & TGTTATAGGGAAAGACTTCG & $91--339$ & 249 \\
\hline & & $\mathrm{R}$ & TTGATGGTAAATGTGACTGG & & \\
\hline \multirow[t]{2}{*}{ aur } & JTJK01000002 & $\mathrm{F}$ & САTGCTTCGTAAAGCATCTC & $301--570$ & 270 \\
\hline & & $\mathrm{R}$ & AATAACGCTGCATGGATTGG & & \\
\hline
\end{tabular}

\section{Assessment of the protease activity}

S. aureus strains were inoculated in TSB and incubated at $37^{\circ} \mathrm{C}$ with shaking at $150 \mathrm{rpm}$ for an appropriate time. Thereafter, cultures were centrifuged at 10000 $\mathrm{rpm}$ for 10 minutes at $4^{\circ} \mathrm{C}$. The obtained supernatants were filtered through 0.2 $\mu \mathrm{M}$ Millipore filter and subsequently used in the assay of protease activity. Protease quantitative assay was carried out on bacterial supernatants according to (Elgaml et al., 2013; Elgaml et al., 2014; Abdel-Sattar et al., 2016). Azocasein $(1.0 \mathrm{mg}$ ) (Sigma-Aldrich, St. Louis, MO, USA) was dissolved in $50 \mathrm{mM}$ Tris $\mathrm{HCl}(\mathrm{pH} 8.0)$ in volume of $0.6 \mathrm{~mL}$. From this solution, $0.2 \mathrm{~mL}$ was mixed with
$0.4 \mathrm{~mL}$ of the supernatants. The reaction mixtures were incubated for an appropriate period of time at $30^{\circ} \mathrm{C}$. Thereafter, $1.4 \mathrm{~mL}$ of $5 \%$ trichloroacetic acid (TCA) was added to cease the reactions. The reaction mixtures were centrifuged at $5000 \mathrm{rpm}$ for 5 minutes at $4{ }^{\circ} \mathrm{C}$ and the obtained supernatants were added to equal volumes of $0.5 \mathrm{M} \mathrm{NaOH}$. Finally, the absorbance was determined at 440 $\mathrm{nm}$. In these experiments, TSB was used as a negative control. 


\section{Assessment of the lipase activity}

Reaction mixtures were prepared by mixing $20 \mu \mathrm{L}$ of the prepared bacterial supernatants (as described above in protease assay), $75 \mu \mathrm{L}$ of $20 \mathrm{mM}$ p-nitro phenyl palmitate (P-NPP) and $0.1 \mathrm{M}$ tris $\mathrm{HCl}$ buffer $(\mathrm{pH} 8.5)$ to a final volume of $3 \mathrm{~mL}$. The reactions were incubated for 10 minutes at $37^{\circ} \mathrm{C}$, and then were frozen at $-20^{\circ} \mathrm{C}$ for another 10 minutes to cease the lipolytic action. The yellow color of the reaction product was spectrophotometrically measured at $410 \mathrm{~nm}$ (Sarkar $\boldsymbol{e t}$ al., 2012; El-baz et al., 2017). In these experiments, TSB was used as a negative control.

\section{Assessment of the staphylokinase activity}

Staphylokinase extraction was carried out according to (Shagufta Naseer $\boldsymbol{e t}$ al. 2014). In a $10 \mathrm{~mL}$ of TSB, colonies of $S$. aureus stains were inoculated and incubated on a shaker incubator at $150 \mathrm{rpm}$ overnight at $37^{\circ} \mathrm{C}$. Then, $\mathrm{OD}_{600}$ of the cultures was adjusted to $0.2-0.275$. In a $10 \mathrm{~mL}$ of TSB, $200 \mu \mathrm{L}$ of the adjusted bacterial suspensions were subcultured and incubated for 24 hours at $37^{\circ} \mathrm{C}$ on a shaker incubator at $200 \mathrm{rpm}$. Then, the cultures were centrifuged for 15 minutes at a speed of $3000 \mathrm{rpm}$ at $4^{\circ} \mathrm{C}$. To the separated supernatants, $40 \%$ (v/v) cold absolute alcohol was added and they were frozen at $-20^{\circ} \mathrm{C}$ for two days to completely precipitate the staphylokinase enzyme. Staphylokinase enzyme was collected as pellets after centrifugation of the enzyme precipitate at $10000 \mathrm{rpm}$ for 20 minutes at $4^{\circ} \mathrm{C}$. The pellets were subsequently dissolved in $0.1 \mathrm{M}$ phosphate buffer solution ( $\mathrm{pH}$ 7.2) (one-tenth of the original supernatant volume) and stockpiled at $-20^{\circ} \mathrm{C}$ for later use. Thereafter, staphylokinase enzyme quantitative assay was established. Initial weights of Eppendorf tubes were measured $\left(\mathrm{X}_{1}\right)$ and $500 \mu \mathrm{L}$ of freshly collected human blood was transferred to the Eppendorf tubes, and incubated for 60 minutes at $37^{\circ} \mathrm{C}$ to enable blood clotting. After complete clotting of blood samples, the produced serum was aspirated and the Eppendorf tubes were reweighed $\left(\mathrm{X}_{2}\right)$. The clot weight was determined by calculating the difference between the second and the first weights $\left(\mathrm{X}_{2}-\mathrm{X}_{1}\right)$. To each Eppendorf tube, $250 \mu \mathrm{L}$ of the previously prepared enzyme extract was added, and then the tubes were incubated at $37^{\circ} \mathrm{C}$ for 2 hours to evaluate clot lysis. After lysis, every Eppendorf tube was weighed subsequent to fluid removal. For each sample, the difference in clot weights (before and after lysis) was calculated. Afterwards the clot lysis percentage, which represents the staphylokinase plasmolytic action was calculated. In these experiments, TSB was used as a negative control.

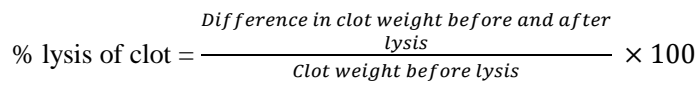

\section{Assessment of the hyaluronidase activity}

Hyaluronidase quantitative assay was executed on previously separated bacterial supernatants (as described above in protease assay) using 1\% agarose plates containing $0.4 \mathrm{mg} / \mathrm{mL}$ of hyaluronic acid (Sigma, H-1504) in $0.3 \mathrm{M}$ sodium phosphate buffer (pH 5.3) and 1\% bovine serum albumin (BSA). Under aseptic conditions, wells were cut in agarose to embody $100 \mu \mathrm{L}$ of the supernatant of tested strains. After 24 hours of incubation at $37^{\circ} \mathrm{C}, 2 \mathrm{M}$ acetic acid was added to flood the plates. The undigested hyaluronic acid was detected as opaque precipitation in conjugation with BSA behind the clear zones of the hydrolyzed hyaluronic acid. The clear zone diameters were measured in millimeters (mm) (Kumar et al., 2012; Abdelkader et al., 2018). In these experiments, TSB was used as a negative control.

\section{Statistical analysis}

Significance of difference was assessed in the results by repeating the experiments three independent times and comparing the data using student's ttest. $\mathrm{P}$ values lower than 0.05 were regarded significantly different.

\section{RESULTS}

\section{Effect of sarA disruption on protease activity}

The UAMS-1 wild type strain and its sarA mutant strain as well as the revertant strain were compared for protease toxins gene expression and toxin production. Expression of $\operatorname{ssp} A, a u r, \operatorname{scp} A$ and $\operatorname{ssp} B$ was significantly increased in the $\operatorname{sar} A$ mutant strain as compared to the wild type and revertant strains (Figure 1A). The relative gene expression of the mutant strain versus the wild type strain was $32.10,81.30,5.85$ and 9.81 for $s s p A$, aur, $s c p A$ and $s s p B$, respectively. Moreover, protease production was significantly higher in the sarA mutant strain than the wild type and revertant strains (Figure 1B). The protease activity of the mutant strain was 2.87 of that of the wild type strain.

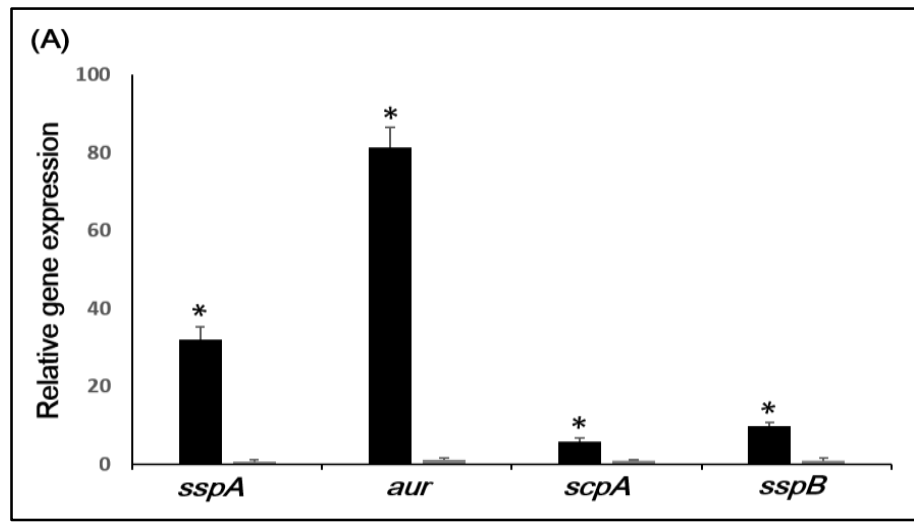

(B)

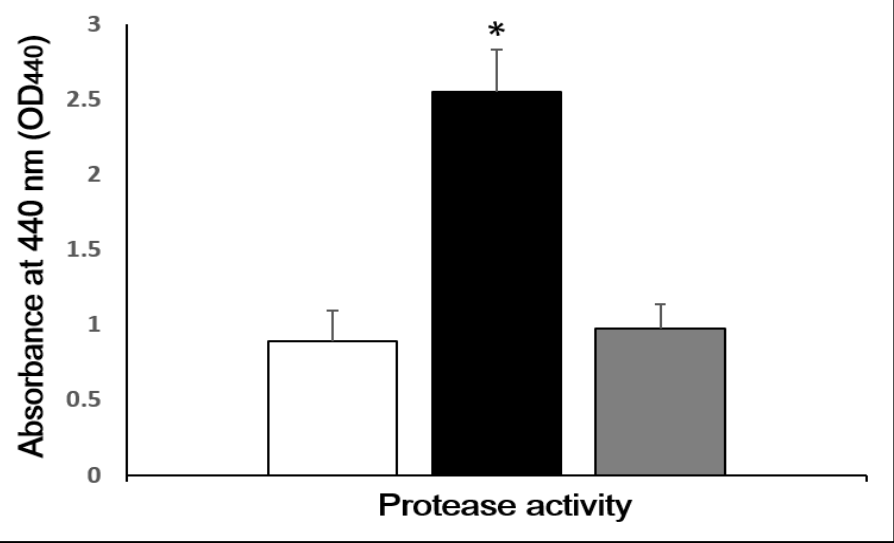

Figure 1 Effect of $s a r A$ disruption on $s s p A$, aur, $s c p A$ and $s s p B$ gene expression levels (A) and on protease activity (B). Data was represented as mean \pm S.D. The asterisk $(*)$ indicates significant difference $(\mathrm{P}<0.05)$ between sarA mutant strain (black bar) and both UAMS-1 wild type strain (white bar) and revertant strain (grey bar).

\section{Effect of sarA disruption on lipase activity}

Mutation of sarA was noticed to downregulate lip1 and lip2 expression (Figure $2 \mathrm{~A})$. The relative gene expression of the mutant strain versus the wild type strain was 0.11 and 0.12 for lip1 and lip2, respectively. This result was confirmed by the quantitative assay of lipase, where, lipase production was significantly altered in the sarA mutant strain compared to both the wild type and revertant strains (Figure 2B). The lipase activity of the mutant strain was 0.11 of that of the wild type strain.

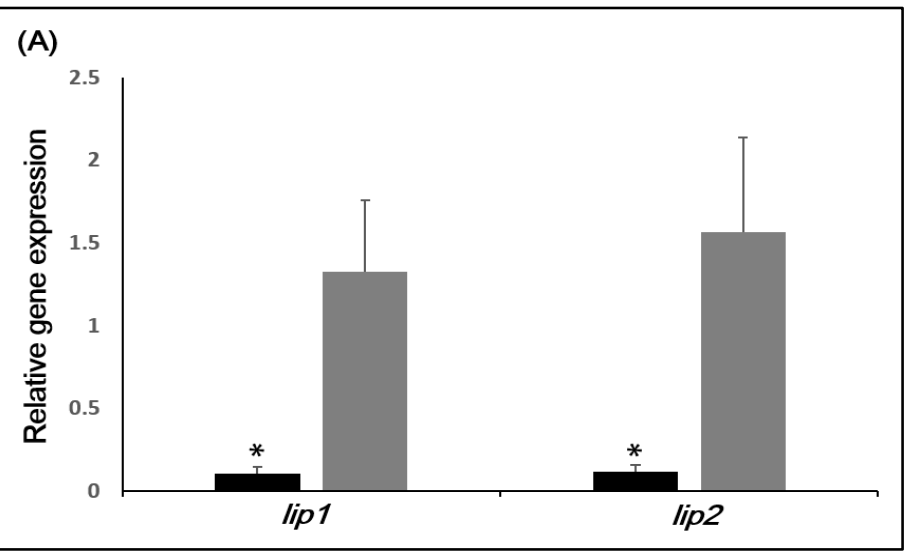




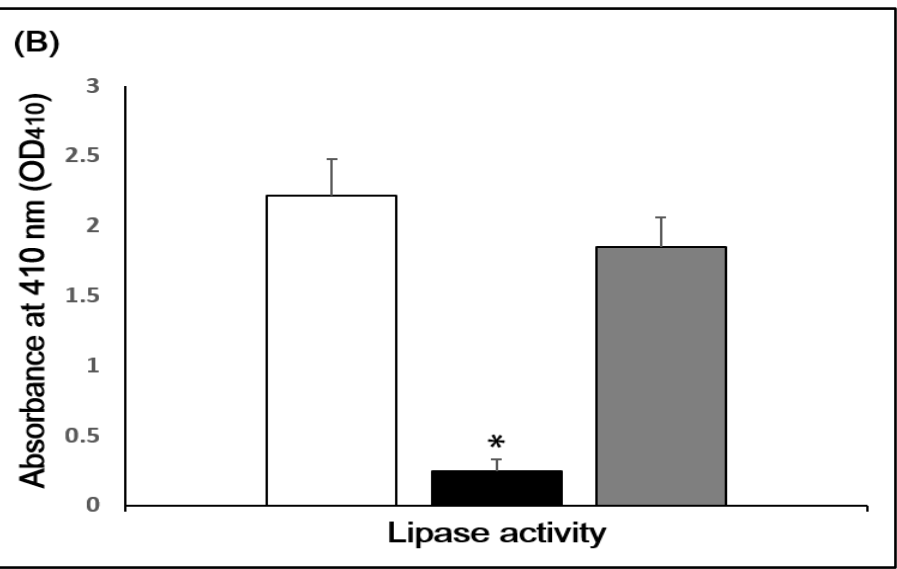

Figure 2 Effect of sarA disruption on lip1 and lip2 gene expression levels (A) and on lipase activity (B). Data was represented as mean \pm S.D. The asterisk (*) indicates significant difference $(\mathrm{P}<0.05)$ between sarA mutant strain (black bar) and both UAMS-1 wild type strain (white bar) and revertant strain (grey bar).

\section{Effect of $\operatorname{sarA}$ disruption on staphylokinase activity}

Expression of $s a k$ was significantly upregulated in the sarA mutant strain in contrast to the wild type and revertant strains (Figure 3A). The relative gene expression of the mutant strain versus the wild type strain was 3.35 for sak. In addition, staphylokinase production level increased noticeably in response to the sarA mutation compared to the wild type and revertant strains (Figure 3B). The staphylokinase activity of the mutant strain was 1.55 of that of the wild type strain.

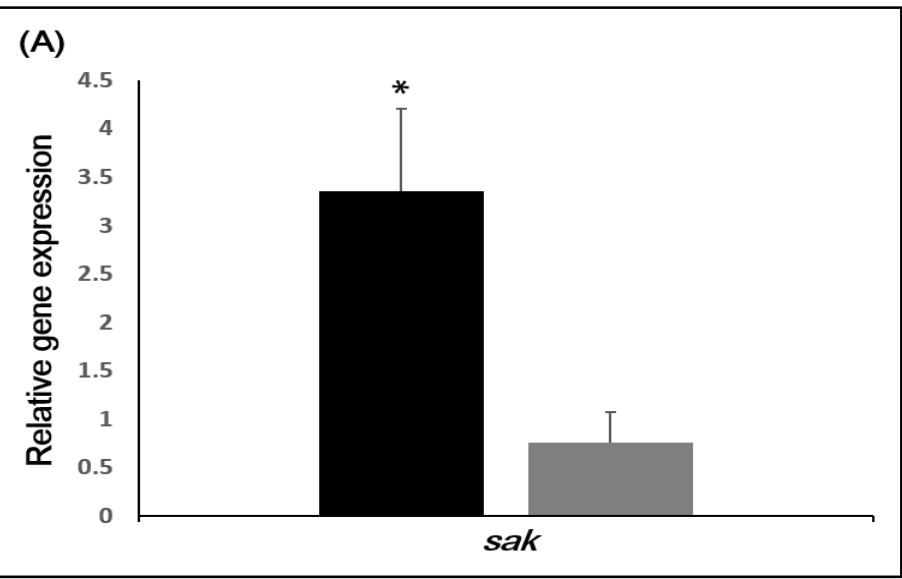

(B)

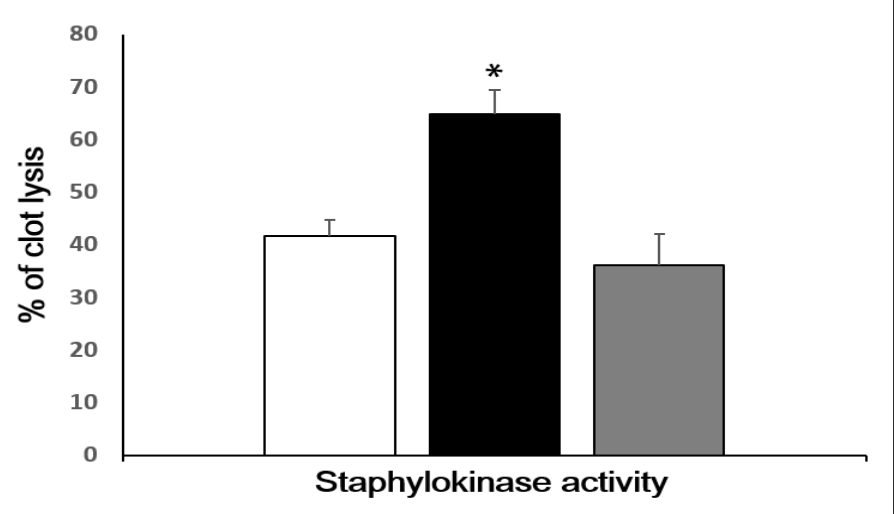

Figure 3 Effect of sarA disruption on sak gene expression level (A) and on staphylokinase activity (B). Data was represented as mean \pm S.D. The asterisk (*) indicates significant difference $(\mathrm{P}<0.05)$ between sarA mutant strain (black bar) and both UAMS-1 wild type strain (white bar) and revertant strain (grey bar).

\section{Effect of $\operatorname{sar} A$ disruption on hyaluronidase activity}

Expression of hysAl and hysA2 was upregulated due to the sarA mutation in comparison to the wild type and revertant strains (Figure 4A). The relative gene expression of the mutant strain versus the wild type strain was 9.89 and 230.89 for hysA1 and hysA2, respectively. Furthermore, quantitative assay of hyaluronidase activity revealed lower production levels in the wild type and revertant strains, and a higher level in the sarA mutant strain (Figure 4B). The hyaluronidase activity of the mutant strain was 2.06 of that of the wild type strain.

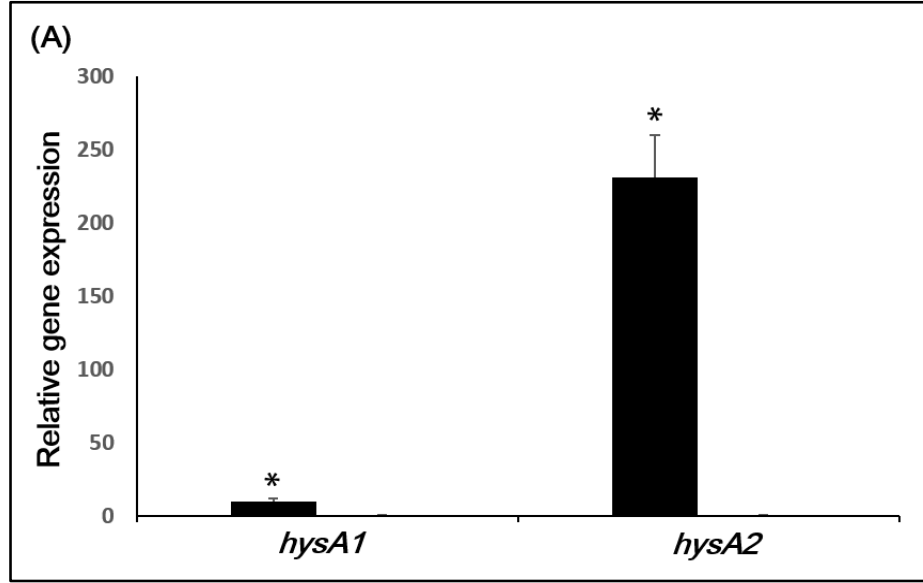

(B)

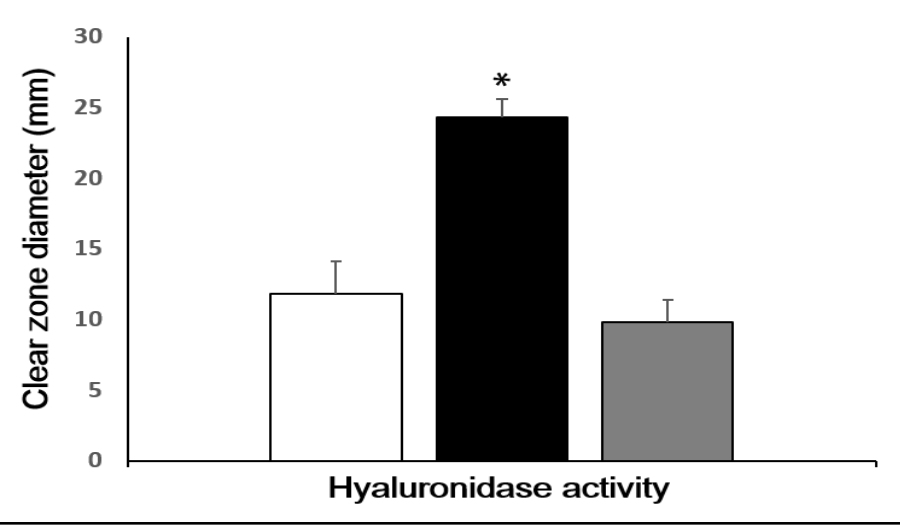

Figure 4 Effect of sarA disruption on hysA1 and hysA2 gene expression levels (A) and on hyaluronidase activity (B). Data was represented as mean \pm S.D. The asterisk $(*)$ indicates significant difference $(\mathrm{P}<0.05)$ between sarA mutant strain (black bar) and both UAMS-1 wild type strain (white bar) and revertant strain (grey bar).

\section{DISCUSSION}

$S$. aureus is an important opportunistic Gram-positive pathogen that is responsible for a number of clinical infections (Chuang-Smith \& Schlievert 2021). Previous studies showed that $S$. aureus is implicated in many clinical cohorts (Mehraj et al., 2016). It is a major cause of skin and soft tissue infections worldwide as it is the causative agent of more than $80 \%$ of the skin and soft tissue infections. It is the most commonly isolated pathogen from infections in surgical sites, purulent cellulitis, wounds and chronic ulcers (Mehraj et al., 2016). It can systemically infect most tissues in the host such as eyes, brain, bones, joints, kidneys, lungs, hearts and muscles (Kuehl et al., 2020).

$S$. aureus is armed with various types of virulence factors that support its pathogenicity and allow its evasion from immune system (Haddad et al., 2018). Expression of virulence factors genes in $S$. aureus is controlled by global regulators such as Agr, SarA, Rot and MgrA (Jenul \& Horswill, 2019). SarA is a 124 amino acid long winged helix protein encoded by sarA locus, which is composed of three overlapped transcripts ( $\operatorname{sar} A \mathrm{P}_{1}, \operatorname{sarA} \mathrm{P}_{3}$ and $\left.\operatorname{sar} A \mathrm{P}_{2}\right)$. It is encoded by a $372 \mathrm{bp}$ sarA open reading frame (ORF) that forms the final SarA protein form (Liu et al., 2006; Cheung et al., 2008). SarA is known to regulate the expression of about 120 genes, of which 76 genes are upregulated, while 44 genes are downregulated either by direct DNA binding or by indirect pathways (Liu et al., 2006; Jones et al., 2008). Murine models infected with sarA mutant $S$. aureus strain showed a suppressed virulence pattern, and reduced susceptibility to septic arthritis and osteomyelitis. Moreover, these models revealed that sarA mutant strain was less likely to produce biofilm, and therefore was more susceptible to antibiotics (Gordon et al., 2013).

Our findings in this study demonstrated that proteases levels [staphylococcal serine protease (SspA), metalloprotease (aureolysin; Aur), staphopain (ScpA) and cysteine protease $(\mathrm{SspB})]$ were increased in the sarA mutant strain when compared to the wild type and revertant strains. This was found to be accordant 
to Zielinska et al., (2012), Atwood et al., (2015), Kong et al., (2016) and Rom et al., (2017). Our results also were found to be accordant with the findings of Karlsson \& Arvidson, (2002), Pragman \& Schlievert, (2004) and Arya \& Princy, (2013), who found that increased sarA expression leaded to a decrease in the proteases levels.

In contrast to proteases, the genes encoding for lipases namely, lip1 and lip2, were found in our study to be downregulated upon the sarA mutation. These findings are similar to those that were found by Blevins et al., (2002) and Pragman \& Schlievert, (2004).

Furthermore, the staphylokinase cofactor encoded by sak was noticed to be upregulated in response to the sarA mutation. This result is found to be in agreement with Ziebandt et al., (2001) and Pragman \& Schlievert, (2004), who found that SarA downregulated staphylokinase production.

Moreover, hyaluronidase was found in higher levels in the staphylococcal sarA mutant strain in comparison to the wild type and revertant strains. Our finding was similar to Hart et al., (2013) and Factor, (2014), who found that hyaluronidase expression increased in the sarA mutant strain as compared to the wild type strain.

\section{CONCLUSION}

To sum up, SarA increased the lipase production. On the other hand, staphylococcal serine protease, metalloprotease, staphopain protease, cysteine protease, staphylokinase and hyaluronate lyases were found to be downregulated by SarA. Therefore, it can be concluded that SarA is an important global regulator that controls the expression and production of many toxins in S. aureus. Our data support previous literature that SarA may act either as a positive regulator (may be through increasing the stability of mRNA of the genes) or a negative regulator (may be through decreasing the transcription of target genes) or may act through other regulatory mechanisms in S. aureus (Figure 5). This can open the door to set novel therapeutic approaches, targeting SarA, for the treatment of certain bacterial infections and help in tackling the overwhelming problem of antibiotic resistance. This can be achieved through using either new key inhibitors or modulators of SarA to control the production of virulence factors that are responsible for the clinical characteristics of each infection.

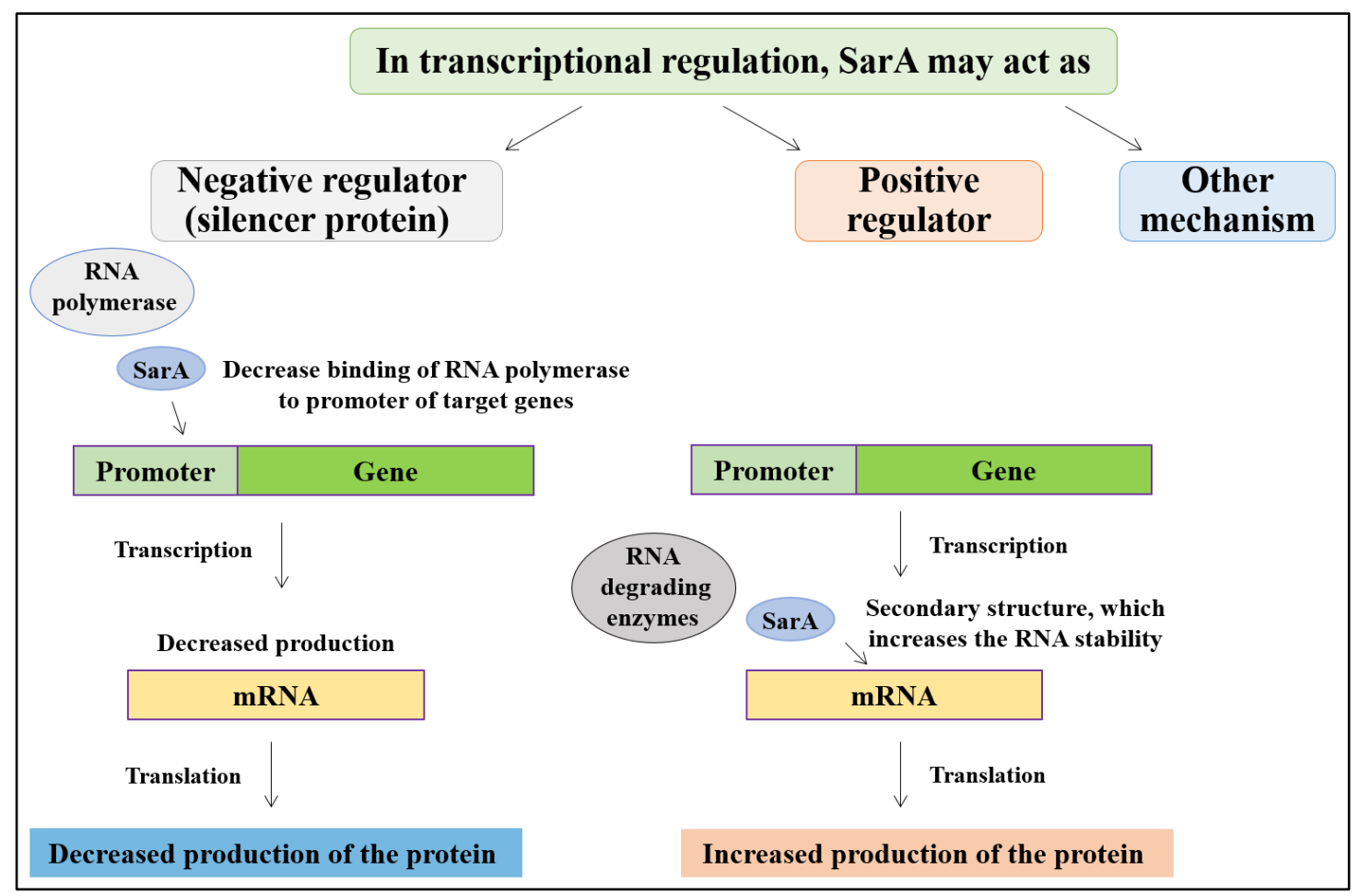

Figure 5 Proposed action of SarA as a global regulator in S. aureus. SarA may act either as a positive regulator (may be through increasing the stability of mRNA of the genes) or a negative regulator (may be through decreasing the transcription of target genes) or may act through other regulatory mechanisms.

Acknowledgment: All thanks and appreciation to Prof. Mark S. Smeltzer, Department of Microbiology and Immunology, University of Arkansas for Medical Sciences, USA, for providing the Staphylococcus aureus UAMS-1 standard strain, its sarA mutant strain and revertant strain. This study was performed at Microbiology and Immunology Department, Faculty of Pharmacy, Mansoura University, Mansoura, Egypt.

Conflict of interest: The authors declare that they have no conflicts of interest.

\section{REFERENCES}

Abdel-Sattar, E. S., Miyoshi, S., \& Elgaml, A. (2016). Regulation of Vibrio mimicus metalloprotease (VMP) production by the quorum-sensing master regulatory protein, LuxR. Journal of Basic Microbioliogy, 56(10), 1051-1058. https://doi.org/10.1002/jobm.201600002

Abdelkader, S. A., El-Mowafy, M., Abdelmegeed, E., \& Hassan, R. (2018) Analysis of hyaluronidase expression by qPCR in Egyptian clinical isolates of Staphylococcus aureus and its correlation with phenotypic plate assay. Advances in Microbiology, 8(7), 614-624. https://doi.org/10.4236/aim.2018.87041

Arvidson, S., \& Tegmark, K. (2001). Regulation of virulence determinants in Staphylococcus aureus. International Journal of Medical Microbiology, 291(2), 159-170. https://doi.org/10.1078/1438-4221-00112

Arya, R., \& Princy, S. A. (2013). An insight into pleiotropic regulators Agr and Sar: molecular probes paving the new way for antivirulent therapy. Future Microbiology, 8(10), 1339-1353. https://doi.org/10.2217/fmb.13.92

Atwood, D. N., Loughran, A. J., Courtney, A. P., Anthony, A. C., Meeker, D. G., Spencer, H. J., . . . Smeltzer, M. S. (2015). Comparative impact of diverse regulatory loci on Staphylococcus aureus biofilm formation. MicrobiologyOpen, 4(3), 436-451. https://doi.org/10.1002/mbo3.250

Becker, K. (2018). Pathogenesis of Staphylococcus aureus. In Staphylococcus aureus (pp. 13-38): Elsevier. doi: https://doi.org/10.1016/C2015-0-04757-8

Beenken, K. E., Blevins, J. S., \& Smeltzer, M. S. (2003). Mutation of sarA in Staphylococcus aureus limits biofilm formation. Infection and Immunity, 71(7), 4206-4211. https://doi.org/10.1128/iai.71.7.4206-4211.2003

Bitrus, A., Peter, O., Abbas, M., \& Goni, M. (2018). Staphylococcus aureus: a review of antimicrobial resistance mechanisms. Veterinary Sciences: Research and Reviews, 4(2), 43-54. https://doi.org/10.17582/journal.vsrr/2018/4.2.43.54 Blevins, J. S., Beenken, K. E., Elasri, M. O., Hurlburt, B. K., \& Smeltzer, M. S. (2002). Strain-dependent differences in the regulatory roles of sarA and $a g r$ in Staphylococcus aureus. Infection and Immunity, 70(2), 470-480. https://doi.org/10.1128/iai.70.2.470-480.2002

Cadieux, B., Vijayakumaran, V., Bernards, M. A., McGavin, M. J., \& Heinrichs, D. E. (2014). Role of lipase from community-associated methicillin-resistan Staphylococcus aureus strain USA300 in hydrolyzing triglycerides into growthinhibitory free fatty acids. Journal of Bacteriology, 196(23), 4044-4056. https://doi.org/10.1128/JB.02044-14

Chen, X., \& Alonzo, F. (2019). Bacterial lipolysis of immune-activating ligands promotes evasion of innate defenses. Proceedings of the National Academy of Sciences, 116(9), 3764-3773. https://doi.org/10.1073/pnas.1817248116

Cheung, A. L., Nishina, K. A., Trotonda, M. P., \& Tamber, S. (2008). The SarA protein family of Staphylococcus aureus. The international Journal of $\begin{array}{llll}\text { Biochemistry } \& \text { Cell Biology, 40(3), 355-361. } & \text {. }\end{array}$ https://doi.org/10.1016/j.biocel.2007.10.032 
Chuang-Smith, O. N., \& Schlievert, P. M. (2021). Staphylococcal enterotoxin C subtypes are differentially associated with human infections and immunobiological activities. mSphere, 6(1), e01153-20. https://doi.org/10.1128/mSphere.01153-20

Connolly, J., Boldock, E., Prince, L. R., Renshaw, S. A., Whyte, M. K., \& Foster, S. J. (2017). Identification of Staphylococcus aureus factors required for pathogenicity and growth in human blood. Infection and Immunity, 85(11), e00337-00317. https://doi.org/10.1128/IAI.00337-17

El-baz, R., Rizk, D. E., Barwa, R., \& Hassan, R. (2017). Virulence characteristics and molecular relatedness of methicillin resistant Staphylococcus aureus harboring different staphylococcal cassette chromosome mec. Microbial Pathogenesis, 113, 385-395. https://doi.org/10.1016/j.micpath.2017.11.021

Elgaml, A., Higaki, K., \& Miyoshi, S.-i. (2013). Regulation system of serine protease production in Vibrio vulnificus strain NCIMB 2137, a metalloproteasegene negative strain isolated from a diseased eel. Aquaculture, 416-417, 315-321. doi: https://doi.org/10.1016/j.aquaculture.2013.09.041

Elgaml, A., Higaki, K., \& Miyoshi, S.-i. (2014). Effects of temperature, growth phase and luxO-disruption on regulation systems of toxin production in Vibrio vulnificus strain L-180, a human clinical isolate. World Journal of Microbiology and Biotechnology, 30(2), 681-691. https://doi.org/10.1007/s11274-013-1501-3

Factor, C.-R. V. (2014). Staphylococcus aureus hyaluronidase is Cod-Y regualted virulence factor. Infection and Immunity, 82(10), 4253-4264. https://doi.org/10.1128/IAI.01710-14

Gordon, C. P., Williams, P., \& Chan, W. C. (2013). Attenuating Staphylococcus aureus virulence gene regulation: a medicinal chemistry perspective. Journal of Medicinal Chemistry, 56(4), 1389-1404. https://doi.org/10.1021/jm3014635

Haddad, O., Merghni, A., Elargoubi, A., Rhim, H., Kadri, Y., \& Mastouri, M. (2018). Comparative study of virulence factors among methicillin resistan Staphylococcus aureus clinical isolates. BMC Infectious Diseases, 18(1), 560 https://doi.org/10.1186/s12879-018-3457-2

Hamzah, C., Mardziah, A., Yeo, C. C., Puah, S. M., Chua, K. H., \& Chew, C. H. (2019). Staphylococcus aureus infections in Malaysia: A review of antimicrobial resistance and characteristics of the clinical isolates, 1990-2017. Antibiotics, 8(3), 128. https://doi.org/10.3390/antibiotics8030128

Hart, M. E., Tsang, L. H., Deck, J., Daily, S. T., Jones, R. C., Liu, H., . Smeltzer, M. S. (2013). Hyaluronidase expression and biofilm involvement in Staphylococcus aureus UAMS-1 and its sarA, agr and sarA agr regulatory $\begin{array}{llll}\text { mutants. } & \text { Microbiology, } & \text { 159(Pt } & \text { 4), }\end{array}$ https://doi.org/10.1099/mic.0.065367-0

Ionescu, B., Ionescu, D., Gheorghe, I., Curuțiu, C., Banu, O., Bleotu, C., . . Bezirtzoglou, E. (2015). Virulence patterns of Staphylococcus aureus hospital strains isolated in Bucharest, Romania. Romanian Biotechnological Letters, 20(3), 10536-10546. https://www.rombio.eu/rbl3vol20/19.pdf

Jenul, C., \& Horswill, A. R. (2019). Regulation of Staphylococcus aureus virulence. Microbiology Spectrum, 7(2), 10.1128/microbiolspec.GPP3-00312018. https://doi.org/10.1128/microbiolspec.GPP3-0031-2018

Jones, R. C., Deck, J., Edmondson, R. D., \& Hart, M. E. (2008). Relative quantitative comparisons of the extracellular protein profiles of Staphylococcus aureus UAMS-1 and its $s a r A$, agr, and sarA agr regulatory mutants using onedimensional polyacrylamide gel electrophoresis and nanocapillary liquid chromatography coupled with tandem mass spectrometry. Journal of Bacteriology, 190(15), 5265-5278. https://doi.org/10.1128/JB.00383-08

Karlsson, A., \& Arvidson, S. (2002). Variation in extracellular protease production among clinical isolates of Staphylococcus aureus due to different levels of expression of the protease repressor sarA. Infection and Immunity, 70(8), 4239-4246. https://doi.org/10.1128/iai.70.8.4239-4246.2002

Kong, C., Neoh, H.-m., \& Nathan, S. (2016). Targeting Staphylococcus aureus toxins: a potential form of anti-virulence therapy. Toxins, 8(3), 72 https://doi.org/10.3390/toxins8030072

Kuehl, R., Morata, L., Meylan, S., Mensa, J., \& Soriano, A. (2020). When antibiotics fail: a clinical and microbiological perspective on antibiotic tolerance and persistence of Staphylococcus aureus. Journal of Antimicrobial Chemotherapy, 75(5), 1071-1086. https://doi.org/10.1093/jac/dkz559

Kumar, D. M., Rejitha, R., Devika, S., Balakumaran, M., Rebecca, A., \& Kalaichelvan, P. (2012). Production, optimization and purification of lipase from Bacillus sp. MPTK 912 isolated from oil mill effluent. Advances in Applied Science Research, 3(2), 930-938. https://www.cabdirect.org/cabdirect/abstract/20123359848

Lacey, K. A., Geoghegan, J. A., \& McLoughlin, R. M. (2016). The role of Staphylococcus aureus virulence factors in skin infection and their potential as vaccine antigens. Pathogens, 5(1), 22. https://doi.org/10.3390/pathogens5010022 Liu, Y., Manna, A. C., Pan, C.-H., Kriksunov, I. A., Thiel, D. J., Cheung, A. L., \& Zhang, G. (2006). Structural and function analyses of the global regulatory protein SarA from Staphylococcus aureus. Proceedings of the National Academy of Sciences, 103(7), 2392-2397. https://doi.org/10.1073/pnas.0510439103

Mauro, T., Rouillon, A., \& Felden, B. (2016). Insights into the regulation of small RNA expression: SarA represses the expression of two sRNAs in Staphylococcus aureus. Nucleic Acids Research, 44(21), 10186-10200. https://doi.org/10.1093/nar/gkw777
Mehraj, J., Witte, W., Akmatov, M. K., Layer, F., Werner, G., \& Krause, G. (2016). Epidemiology of Staphylococcus aureus nasal carriage patterns in the community. Current Topics in Microbiology and Immunology, 398, 55-87. https://doi.org/10.1007/82_2016_497

Morrison, J. M., Anderson, K. L., Beenken, K. E., Smeltzer, M. S., \& Dunman, P. M. (2012). The staphylococcal accessory regulator, SarA, is an RNA-binding protein that modulates the mRNA turnover properties of late-exponential and stationary phase Staphylococcus aureus cells. Frontiers in Cellular and Infection Microbiology, 2, 26. https://doi.org/10.3389/fcimb.2012.00026

Nguyen, M.-T., Luqman, A., Bitschar, K., Hertlein, T., Dick, J., Ohlsen, K., . . Götz, F. (2018). Staphylococcal (phospho) lipases promote biofilm formation and host cell invasion. International Journal of Medical Microbiology, 308(6), 653 663. https://doi.org/10.1016/j.ijmm.2017.11.013

Pietrocola, G., Nobile, G., Rindi, S., \& Speziale, P. (2017). Staphylococcus aureus manipulates innate immunity through own and host-expressed proteases. Frontiers in Cellular and Infection Microbiology, 7, 166. https://doi.org/10.3389/fcimb.2017.00166

Pragman, A. A., \& Schlievert, P. M. (2004). Virulence regulation in Staphylococcus aureus: the need for in vivo analysis of virulence factor regulation. FEMS Immunology \& Medical Microbiology, 42(2), 147-154. https://doi.org/10.1016/j.femsim.2004.05.005

Rom, J. S., Atwood, D. N., Beenken, K. E., Meeker, D. G., Loughran, A. J., Spencer, H. J., . . . Smeltzer, M. S. (2017). Impact of Staphylococcus aureus regulatory mutations that modulate biofilm formation in the USA300 strain LAC on virulence in a murine bacteremia model. Virulence, 8(8), 1776-1790. https://doi.org/10.1080/21505594.2017.1373926

Sarkar, P., Yamasaki, S., Basak, S., Bera, A., \& Bag, P. K. (2012). Purification and characterization of a new alkali-thermostable lipase from Staphylococcus aureus isolated from Arachis hypogaea rhizosphere. Process Biochemistry, 47(5), 858-866. https://doi.org/10.1016/j.procbio.2012.02.023

Schmittgen, T. D., \& Livak, K. J. (2008). Analyzing real-time PCR data by the comparative C T method. Nature Protocols, 3(6), 1101-1108. https://doi.org/10.1038/nprot.2008.73

Shagufta Naseer, B., Ravi, M., Gaddad, S. M., \& Jayaraj, Y. M. (2014) Screening of staphylokinase producing Staphylococcus aureus from clinical samples. 4(2), 46-48. https://www.isroset.org/journal/IJSRBS/index.php

Singh, V., \& Phukan, U. J. (2019). Interaction of host and Staphylococcus aureus protease-system regulates virulence and pathogenicity. Medical Microbiology and Immunology, 208(5), 585-607. https://doi.org/10.1007/s00430-018-0573-y

Tam, K., \& Torres, V. J. (2019). Staphylococcus aureus secreted toxins and extracellular enzymes. Microbiology Spectrum, 7(2), 10.1128/microbiolspec.GPP3-0039-2018.

https://doi.org/10.1128/microbiolspec.GPP3-0039-2018

Tong, S. Y., Davis, J. S., Eichenberger, E., Holland, T. L., \& Fowler, V. G. (2015). Staphylococcus aureus infections: epidemiology, pathophysiology, clinical manifestations, and management. Clinical Microbiology Reviews, 28(3), 603-661. https://doi.org/10.1128/CMR.00134-14

Ziebandt, A. K., Weber, H., Rudolph, J., Schmid, R., Höper, D., Engelmann, S., \& Hecker, M. (2001). Extracellular proteins of Staphylococcus aureus and the role of SarA and $\sigma$ B. Proteomics, 1(4), 480-493. https://doi.org/10.1002/16159861(200104)1:4<480::AID-PROT480>3.0.CO;2-O

Zielinska, A. K., Beenken, K. E., Mrak, L. N., Spencer, H. J., Post, G. R., Skinner, R. A., . . S Smeltzer, M. S. (2012). SarA-mediated repression of protease production plays a key role in the pathogenesis of Staphylococcus aureus USA 300 isolates. Molecular Microbiology, 86(5), 1183-1196. https://doi.org/10.1111/mmi.12048 